\title{
Cell Saver en operación cesárea compleja. Reporte de un caso
}

\author{
Márquez D. ${ }^{1,2}$, Valencia N. ${ }^{3}$, Aranda F. ${ }^{1,3}$ \\ 1 Universidad de Valparaíso, Viña del Mar, Chile. \\ 2 Viña del Mar, Chile. \\ 3 Hospital Gustavo Fricke, Viña del Mar, Chile.
}

Introducción: En el último tiempo, la estrategia de Rescate Celular ("Cell Saver") se ha posicionado como una alternativa atractiva para el manejo de la hemorragia perioperatoria, siendo uno de los principales ejes en la estrategia de ahorro sanguíneo. Como principal ventaja destaca la disminución de transfusión alogénica, y con ello las complicaciones asociadas. En Chile, su uso es limitado; más aún, en obstetricia la experiencia es incipiente. Por esto, presentamos un reporte de caso de una paciente gestante con graves comorbilidades, que condicionan un alto riesgo de sangrado, sometida a cesárea electiva en un hospital público, y destacando el uso de Cell Saver en la estrategia de ahorro sanguíneo.

Métodos: Reporte de caso. Mujer 36 años, multípara de uno, embarazo de $32+3$ semanas, antecedentes de Diabetes mellitus II no insulinorequirente, daño hepático crónico Child A por virus hepatitis C. Várices esofágicas Grado III por hipertensión portal, abundante circulación colateral en pared abdominal, esplenomegalia con secuestro secundario y bicitopenia (anemia - trombocitopenia). Se hospitaliza para interrupción del embarazo por vía cesárea con tal de evitar expulsivo que pudiera condicionar un sangrado digestivo durante el parto. Exámenes de laboratorio destacan, hematocrito $31,9 \%$, hemoglobina $10,2 \mathrm{~g} / \mathrm{dl}$, plaquetas $44.000 / \mathrm{mm} 3$, protrombina $77 \%$, INR 1,19, TTPk 26 segundos, fibrinógeno $310 \mathrm{mg} / \mathrm{dl}$ y sin signos de insuficiencia hepática. Grupo O Rh +. Ecografía obstétrica demuestra embarazo único normal, compatible con edad gestacional. Se planifica cesárea electiva y esterilización quirúrgica, previa maduración pulmonar fetal con corticoides. Previo a pabellón se transfunde con 6 unidades de plaquetas. Se utilizó durante todo el procedimiento (salvo en la aspiración de líquido amniótico) el equipo de recuperación sanguínea, Autolog (Medtronic), lográndose aspirar $380 \mathrm{ml}$ de sangre, de los cuales fue posible transfundir $126 \mathrm{ml}$ de glóbulos rojos (GR) Concentrados en el postoperatorio inmediato.

Resultados: Sin signos de sangrado en postoperatorio. Control de exámenes a las $24 \mathrm{~h}$. Hematocrito 26,8\%, hemoglobina $8,8 \mathrm{~g} / \mathrm{dl}$. Egresa a las $48 \mathrm{~h}$ a sala común, siendo finalmente dada de alta al quinto día postquirúrgico. La paciente no requirió transfusión de GR durante toda su hospitalización.

Conclusiones: El Cell Saver para minimización de pérdidas hemáticas contribuyó a evitar la anemia, evitando la transfusión autóloga y todos los riesgos asociados a ella, además de aportar una herramienta de seguridad frente al eventual sangrado masivo. Se considera un procedimiento exitoso y posiciona al rescate celular como una terapia fundamental en el alto riesgo de sangrado perioperatorio.

https://doi.org/10.25237/congresoclasa2019.20 